\title{
Food and Feeding Behaviour of Kingfishers (Family: Alcedinidae) in Selected Water Bodies in Osun State, Nigeria
}

\section{Oguntimehin BE ${ }^{1}$, Akinpelu $\mathrm{AI}^{1}$ and Oyelade $0 \mathrm{~J}^{2}$}

${ }^{1}$ Department of Zoology, Obafemi Awolowo University, Ile-Ife, Nigeria

${ }^{2}$ Natural History Museum, Obafemi Awolowo University, Ile-Ife, Nigeria

*Corresponding author: Oguntimehin Bukola, Department of Zoology Obafemi Awolowo University, Ile-Ife, Nigeria, Email: bukkyoguns09@gmail.com

\section{Research Article \\ Volume 2 Issue 5}

Received Date: October 02, 2019

Published Date: October 16, 2019

DOI: $10.23880 /$ izab-16000179

\section{Abstract}

Many countries are experiencing different health challenges as a result of polluted water caused by industrial pollution and contamination by agricultural run-off. Pollution also kills the fishes that kingfishers feed on thereby limiting the fish population. This study identified the species of kingfishers present around some selected water bodies (Opa, Akinrinade, Osinmo, and Osu Reservoirs) in Osun State, Nigeria. It also determined the food and feeding preferences of various species of kingfishers in the selected reservoirs. These were with a view to determine the food and feeding ecology of kingfishers in Osun State.

A total of 2,215 individuals and 5 species of kingfishers were observed in the field during the sampling period. The mean comparison of the species across the sites revealed that Opa Reservoir had the highest $(63.83 \pm 12.90)$ abundance of species, followed by Akinrinade Reservoir with $(57.5 \pm 11.18)$ while Osu Reservoir had the lowest $(11.33 \pm 6.12)$.The species abundance in Opa and Akinrinade Reservoirs were not significantly $(p>0.05)$ different from each other but significantly $(\mathrm{p}<0.05)$ different from Osu reservoir. Also, species abundance in Osinmo and Akinrinade Reservoirs were not significantly $(\mathrm{p}>0.05)$ different from each other but significantly $(\mathrm{p}<0.05)$ different from Osu Reservoir. This study showed that kingfishers preyed on several species which comprised of insects (dragonfly, grasshopper, damselfly, butterfly, and ants), water snail and fish (tilapia, fry of tilapia, barbus).

Keywords: Reservoirs; Species; Kingfishers; Food; Prey

\section{Introduction}

Kingfishers belong to the Order Coraciiformes and Family Alcedinidae. Other members of coraciiformes include the Bee eaters, Horn bills, Rollars and Hoopops.
Alcedinidae comprises approximately 17 genera and 91 species. They were formerly in a single family but there are three distinct lineages that are well-supported by a range of molecular, anatomical, and moult evidence $[1,2]$. Sibley, et al. [3] separated these group into three 


\section{International Journal of Zoology and Animal Biology}

subfamilies based on the degree of divergence shown by DNA hybridization evidence into: Alcedininae (river kingfishers), Halcyoninae (tree kingfishers), and Cerylinae (water kingfishers). They all have large heads, long and sharp pointed bills, short legs, and stubby tails. The bills of kingfishers are thick but they vary in shape in accordance with foraging habits of each species. Many species also have a pale collar, distinctive crest, bright plumage with few differences between the sexes [4-6].

They have a cosmopolitan distribution, with most species found outside the America. Kingfishers are an easily recognized group of often colourful birds around the world sometimes perching for up to two hours while foraging. The species' patience has impressed several observers [7]. Most species are tropical in distribution with slight majority found only in the forests or open woodland habitats often near water. About 17 species are found in the wooded savannas, 31 species in aquatic environment while 44 species live in closed-canopy forests and one species lives in the desert scrub. The main habitat requirements for kingfishers are food and nest site availability [4,8]. Despite their name, not all kingfishers are fishing specialist, they consume a wide range of prey, as well as fish, and other unspecialized diets that include a high proportion of insects usually caught by swooping down from a perch or by plungediving from a waterside perch [7]. Kingfishers are usually thought to live near rivers and eat fish but some species live away from water and eat small invertebrates. Many kingfishers take whatever prey is available which shows they are highly adaptable or opportunistic. Like other members of their Order Coraciiformes, they nest in cavities, usually tunnels dug into the natural or artificial banks in the ground. Kingfishers hunt from a perch above the water, on a branch, or riverbank with bill pointing down as it searches for prey. The food is mainly fish such as minnows, sticklebacks, small roach and trout [7]. Water clarity is a key factor in the kingfisher's survival, so the water needs to be clear enough for the bird to see its tiny prey as it skims across the surface for aquatic insects and crustaceans or peers from an overhanging branch. However, the feeding habits of kingfishers have been rarely studied though Campos, et al. [9] noted small fish and freshwater crustaceans (crabs and prawns) as its main food. At night, most kingfishers roost alone on a perch within their territory with most species being sedentary and few species being migratory. All but one species are diurnal, the nocturnal species is hooked-billed kingfisher (Melidora macrorrhina), which feeds largely at night.
Kingfishers have very good sight for hunting which allows them to accurately judge the distance to a prey item by turning their heads slightly. The biggest threat facing most kingfishers populations is the destruction or alteration of their habitats by pollution of water bodies, logging and various developments. Significant numbers have also been killed by shooting, poisoning from pesticides etc. Some of the species of kingfishers are endangered, while some are vulnerable, some nearly threatened and some are data deficient while some are under protection by Migratory Bird Treaty Act [10].

\section{Materials and Methods}

\section{Study Area}

This research was carried out within Osun State which has a total area of $9251 \mathrm{~km}^{2}$ and coordinates latitude and longitude $7^{\circ} 00^{\prime} \mathrm{N} 4^{\circ} 00^{\prime} \mathrm{E}$ and $8^{\circ} 14^{\prime} \mathrm{N}, 5^{\circ} 00^{\prime} \mathrm{E}$ [11]. The state experiences a tropical climate while the local vegetation is the lowland rain forest type that favour agriculture. The sampling locations (Opa Reservoir in Ile Ife, Akinrinade Reservoir in Moro, Osinmo Reservoir in Ejigbo and Osu Reservoir in Osu) were randomly selected for the research.

\section{Brief Description of the Sampling Sites}

\section{Opa Reservoir}

Opa Reservoir was established in 1978 by the impoundment of Opa River which took its source from Oke Opa Hills. The climate of the area is characterized by two distinct seasons, dry and wet seasons. The wet season extends from April to October and is marked with high rainfall; while dry season on the other hand extends from November to March [12]. It has a mean annual precipitation of $1000-1250 \mathrm{~mm}$ and a mean annual temperature of about $27^{\circ} \mathrm{C}[13,14]$.

\section{Osinmo Reservoir}

It was created in 2005 by the impoundment of Ataro River which took its source from Iware in Oyo State. It has a catchment area of about $102 \mathrm{~km}^{2}$. The reservoir basin extends from Longitude $04^{\circ} 21.2^{\prime} \mathrm{E}$ to $04^{\circ} 21.7^{\prime} \mathrm{E}$ and from Latitude $07^{\circ} 52.8^{\prime} \mathrm{N}$ to $07^{\circ} 53.2^{\prime} \mathrm{N}$. It occupies an undulating terrain with the highest altitude of $365.76 \mathrm{~m}$ above the sea level. The vegetation of the area is a lowland rain forest with some areas of derived grassland. There is heavy rainfall between July and September of each year and an annual rainfall of $130.88 \mathrm{~mm}$ has been recorded [15]. 


\section{International Journal of Zoology and Animal Biology}

\section{Akinrinade Reservoir}

Akinrinade Reservoir located in Moro, Ife North Local Government of Osun State was constructed in 1980, primarily for fishing and it is characterized by dense forest around the Reservoir.

\section{Osu Reservoir}

Osu Reservoir is situated in Osu, Atakumosa West Local Government area of Osun State, Nigeria. This reservoir was impounded in the year 2005 by Osun state government in conjunction with Osun State Water Corporation. The surface area of the reservoir is about $0.118 \mathrm{~km}^{2}$.

\section{Sampling Technique}

In each of the sampling sites, observation and data collection were done for a period of twelve months April to October, 2017 for the rainy season while November to March, 2018 for the dry season. Following local informants and personal observations of brightly coloured plumage, various sizes of kingfishers and perching characteristics were used in identifying various species. Confirmatory identification was done using a (Borrow Nik and Ron Demey 2014) on the field [16]. Observations were limited to morning, afternoon and evening at selected periods based on the information got from the preliminary observations because they were present nearly throughout the day. Identified kingfishers were counted singly in numerical order to give more information about their pattern of feeding. The observations took place once in all the sampling sites on different dates. Where there were large populations and at long distances binoculars was used in getting a clearer picture of the way they feed and their counts. Nest and roosting places of kingfishers were located and visited to collect their faecal samples which were used to determine remnants of food, i.e. the undigested food left in the faecal pellets to ascertain the food they consume. Collections took place every second week of the month for the period of twelve months at the entire study site. A reference collection of representative and distinctive body of insects, fishes and plant seeds collected from the study site were compared with the hard parts from the faecal samples. The insects collected were identified in Museum of Natural History (O.A.U), fishes were identified in fishery section in Zoology Department (O.A.U) while the seeds of some plants were identified in Ife Herbarium in the Botany Department (O.A.U). Fresh faecal samples collected at each sampling site were sorted in the laboratory. Water was used to soften the faecal samples before sorting to prevent the hard parts from breaking after which all of the hard parts were sorted and examined at 40x under the microscope or magnifying lens through comparing of hard part with the reference collection and then identified up to order level.

\section{Data Analysis}

Data were subjected to one-way analysis of variance (ANOVA), Mean separation was done using Duncan's New Multiple Range. The statistical package used for analysis was statistical package for social scientists (SPSS) version 17.0.Graphs were plotted using Excel and Graph pad prism version 5 . The excel descriptive statistical packages such as frequency of distribution, means, percentages and charts were also used in the presentation of findings from this work.

\section{Results}

A total of 2215 individuals and 5 species of kingfishers were seen during period of sampling at all their feeding sites. It was observed that different species of kingfishers came out to feed at different periods of the day while some fed mostly at the early hours and late hours of the day. The woodland kingfishers which were most widely spread in the four sampling sites fed mostly at the afternoon and towards evening with variation observed between September and October when the rainfall was heavy.

\section{The Species Composition, Mean and Frequency of Occurrence of Kingfishers across the Sampling Sites for Period of Twelve Months}

Table 1 show that woodland kingfisher had the highest percentage composition with $57.2 \%$, followed by pied kingfisher with $42.5 \%$ and the giant kingfisher had the least percentage frequency with $0.39 \%$ at Opa sampling site. At Osu Reservoir, only one species of kingfisher was found i.e., the woodland kingfisher with a total of 136 (Table 2). The highest percentage composition recorded at Akinrinade sampling site was for woodland kingfisher with $54.6 \%$, followed by pied kingfisher with $25.1 \%$, while African dwarf kingfisher had the least percentage composition of $20.3 \%$ (Table 3). At Osinmo Reservoir, the highest percentage composition was woodland kingfisher with $57.0 \%$ while the lowest percentage composition was for the blue breasted kingfishers with $43.0 \%$ (Table 4). 


\section{International Journal of Zoology and Animal Biology}

\begin{tabular}{|c|c|c|c|c|c|c|}
\hline Common name & Species name & Subfamily & Total & $\begin{array}{c}\text { Frequency of } \\
\text { occurrence }\end{array}$ & Mean & $\begin{array}{c}\text { Percentage } \\
\text { composition\% }\end{array}$ \\
\hline Woodland kingfisher & Halcyon senegalensis & Halcyoninae & 438 & 125 & 3.5 & 57.2 \\
\hline Pied kingfishers & Ceryle rudis & Cerylinae & 325 & 85 & 3.82 & 42.5 \\
\hline Giant kingfishers & Megaceryle maxima & Cerylinae & 3 & 3 & 1 & 0.39 \\
\hline Total & & & 766 & 213 & 8.32 & 100 \\
\hline
\end{tabular}

Table 1: The Total number of various Species of Kingfishers observed and counted frequency of occurrence, percentage composition and their mean in Opa Reservoir for period of twelve months.

\begin{tabular}{|c|c|c|c|c|c|c|}
\hline Common name & Species name & Subfamily & Total & $\begin{array}{c}\text { Frequency of } \\
\text { occurrence }\end{array}$ & Mean & $\begin{array}{c}\text { Percentage } \\
\text { composition\% }\end{array}$ \\
\hline Woodland kingfisher & Halcyon senegalensis & Halcyoninae & 136 & 61 & 2.23 & 100 \\
\hline Total & & & 136 & 61 & 2.23 & 100 \\
\hline
\end{tabular}

Table 2: The Total number of various species of Kingfishers counted, Frequency of Occurrence, percentage composition and their mean in Osu Reservoir for period of twelve months.

\begin{tabular}{|c|c|c|c|c|c|c|}
\hline Common name & Species name & Subfamily & Total & $\begin{array}{c}\text { Frequency of } \\
\text { occurrence }\end{array}$ & Mean & $\begin{array}{c}\text { Percentage } \\
\text { composition\% }\end{array}$ \\
\hline Woodland kingfisher & Halcyon senegalensis & Halcyoninae & 377 & 95 & 3.97 & 54.6 \\
\hline Pied kingfishers & Ceryle rudis & Cerylinae & 173 & 58 & 2.98 & 25.1 \\
\hline African dwarf kingfishers & Ispidina lecontei & Alcedininae & 140 & 48 & 2.91 & 20.3 \\
\hline Total & & & 690 & 201 & 9.86 & 100 \\
\hline
\end{tabular}

Table 3: The Total number of various species of Kingfishers counted, Frequency of occurrence, percentage composition and their mean in Akinrinade's Reservoir for period of twelve Months.

\begin{tabular}{|c|c|c|c|c|c|c|}
\hline Common name & Species name & Subfamily & Total & $\begin{array}{c}\text { Frequency of } \\
\text { occurrence }\end{array}$ & Mean & Percentage v \\
\hline Woodland kingfisher & Halcyon senegalensis & Halcyoninae & 355 & 91 & 3.9 & 57 \\
\hline Blue breasted kingfisher & Halcyon malimbica & Halcyoninae & 268 & 63 & 3.17 & 43 \\
\hline Total & & & 623 & 154 & 7.07 & 100 \\
\hline
\end{tabular}

Table 4: The Total number of various species of Kingfishers counted, Frequency of occurrence, percentage composition and their mean in Osinmo Reservoir for period of twelve Months.

\section{Number of Kingfishers Counted for the Twelve Months across the Sampling Sites}

A total of $766(63.8 \pm 12.90)$ of kingfishers was counted at Opa sampling site. The highest numbers of birds were recorded in the months of June and December with total of $77(10.05 \%)$ each, followed by January with total of 76 (9.92\%) and September had lowest number of birds with total number of 38 (4.96\%). At Osu Reservoir, a total of $136(11.3 \pm 6.12)$ birds was recorded .The highest number was observed in the month of February with total of 22 (16.17\%), followed by the month of April with total of 18 $(13.29 \%)$ while the lowest numbers was recorded in the month of January with total of $3(2.20 \%)$ of birds also, a total number of $690(57.5 \pm 11.18)$ birds were recorded at
Akinrinade sampling site. Across the twelve months, highest number of birds was recorded in the month of February with total number of 75 (10.86\%), followed by August with total number of 71 .

\section{Mean Comparison of Species Abundance across Sites}

The mean comparison of the species across the sites revealed that Opa Reservoir had the highest $(63.83 \pm 12.90)$ abundance of species, followed by Akinrinade Reservoir with (57.5 \pm 11.18$)$ while Osu Reservoir had the lowest $(11.33 \pm 6.12)$ abundance of species (Table 5). The species abundance in Opa and Akinrinade Reservoirs were not significantly ( $p>0.05$ ) 
different from each other but significantly $(\mathrm{p}<0.05)$ different from Osu Reservoir. Also, species abundance in Osinmo and Akinrinade Reservoirs were not significantly $(p>0.05)$ different from each other but significantly $(p<0.05)$ different from Osu Reservoir (Table 5).

\begin{tabular}{|c|c|}
\hline Sites & Species Abundance \\
\hline Osu Reservoir & $11.33 \pm 6.12 \mathrm{c}$ \\
\hline Osinmo Reservoir & $51.92 \pm 6.22^{\mathrm{b}}$ \\
\hline Akinrinade Reservoir & $57.5 \pm 11.18^{\mathrm{ab}}$ \\
\hline Opa Reservoir & $63.83 \pm 12.90^{\mathrm{a}}$ \\
\hline P-Value & 8.56 \\
\hline
\end{tabular}

Table 5: Mean and Standard Deviation Comparison of Species Abundance across Sites.

\section{Mean Comparison between Numbers of Species of Kingfishers Observed across the Study Sites}

There were significant differences in the mean comparison of kingfisher recorded for the period of twelve months across study sites. The number of kingfisher recorded in Opa, Akinrinade and Osinmo Reservoirs were not significantly different $(p>0.05)$ from each other but significantly different from Osu Reservoir $(0.36 \pm 0.81)$ in the month of June and July (Table 6). Also, the number of kingfisher recorded in Akinrinade Reservoir had the highest mean $(2.84 \pm 1.65)$ value in the month of August and was highly significantly different $(\mathrm{p}<0.05)$ from other sampling sites. However, across most of the months, numbers of kingfishers observed in Osu Reservoir was significantly different $(\mathrm{p}<0.05)$ from $0 \mathrm{pa}$, Akinrinade and Osinmo Reservoirs (Table 6).

\begin{tabular}{|c|c|c|c|c|c|}
\hline Months & OPA & OSU & Akinrinade & Osinmo & P-value \\
\hline April & $2.00 \pm 1.41^{\mathrm{a}}$ & $0.72 \pm 0.98^{\mathrm{a}}$ & $2.16 \pm 1.57^{\mathrm{a}}$ & $1.88 \pm 1.59^{\mathrm{b}}$ & 0.7 \\
\hline May & $2.48 \pm 1.29^{\mathrm{a}}$ & $0.56 \pm 0.96^{\mathrm{ab}}$ & $1.72 \pm 1.20^{\mathrm{b}}$ & $1.88 \pm 1.39^{\mathrm{c}}$ & 0.6 \\
\hline June & $3.08 \pm 2.28^{\mathrm{a}}$ & $0.36 \pm 0.81^{\mathrm{b}}$ & $2.72 \pm 1.45^{\mathrm{a}}$ & $2.48 \pm 2.02^{\mathrm{a}}$ & 0.9 \\
\hline July & $2.88 \pm 2.47^{\mathrm{a}}$ & $0.56 \pm 1.35^{\mathrm{b}}$ & $2.64 \pm 1.77^{\mathrm{a}}$ & $2.36 \pm 1.95^{\mathrm{a}}$ & 1 \\
\hline August & $2.48 \pm 1.75^{\mathrm{ab}}$ & $0.48 \pm 0.96^{\mathrm{c}}$ & $2.84 \pm 1.65^{\mathrm{a}}$ & $1.84 \pm 1.51^{\mathrm{b}}$ & 0.8 \\
\hline September & $1.52 \pm 1.08^{\mathrm{a}}$ & $0.00 \pm 0.00^{\mathrm{b}}$ & $1.96 \pm 1.59^{\mathrm{a}}$ & $1.84 \pm 1.49^{\mathrm{a}}$ & 0.6 \\
\hline October & $1.88 \pm 1.16^{\mathrm{a}}$ & $0.48 \pm 0.96^{\mathrm{b}}$ & $2.04 \pm 1.39^{\mathrm{a}}$ & $2.00 \pm 1.77 \mathrm{a}$ & 0.7 \\
\hline November & $2.72 \pm 1.76^{\mathrm{a}}$ & $0.24 \pm 0.72^{\mathrm{c}}$ & $1.56 \pm 1.44^{\mathrm{b}}$ & $2.00 \pm 1.97^{\mathrm{ab}}$ & 0.8 \\
\hline December & $3.08 \pm 2.11^{\mathrm{a}}$ & $0.48 \pm 1.12^{\mathrm{b}}$ & $2.36 \pm 1.41^{\mathrm{a}}$ & $2.20 \pm 1.91^{\mathrm{a}}$ & 0.9 \\
\hline January & $3.04 \pm 2.28^{\mathrm{a}}$ & $0.12 \pm 0.43^{\mathrm{b}}$ & $2.16 \pm 1.34^{\mathrm{a}}$ & $2.2 \pm 1.70^{\mathrm{a}}$ & 0.8 \\
\hline February & $2.52 \pm 1.38^{\mathrm{a}}$ & $0.88 \pm 1.56^{\mathrm{b}}$ & $3.00 \pm 1.68^{\mathrm{a}}$ & $2.44 \pm 1.63^{\mathrm{a}}$ & 0.9 \\
\hline March & $2.96 \pm 1.67^{\mathrm{a}}$ & $0.56 \pm 1.35^{\mathrm{c}}$ & $2.44 \pm 1.47^{\mathrm{ab}}$ & $1.8 \pm 1.38^{\mathrm{b}}$ & 0.8 \\
\hline
\end{tabular}

Table 6: Mean and Standard Deviation Comparison between Numbers of species of kingfishers observed across the Study Sites.

\section{Preference of Different Prey Items Fed Upon by Kingfisher across the Sites}

The preference of different food items preyed upon by kingfisher at Opa Reservoir revealed that barbus had the highest preference by pied kingfisher, followed by grasshopper fed on by Woodland Kingfisher while butterfly and ants had lowest preference fed on by woodland (Figure 1). In Osu Reservoir, dragonfly had the highest preference, followed by damselfly, praying mantis and grasshopper with equal preference while butterfly and ants had the lowest preference (Figure 2).
At Osinmo Reservoir, grasshopper had the highest preference fed on by Woodland kingfisher, followed by praying mantis fed on by Blue breasted while ants had the lowest preference fed on by Woodland Kingfisher (Figure 3). However, at Akinrinade Reservoir, tilapia fish had the highest preference fed on by Pied Kingfisher while dragonfly had the lowest preference fed on by African dwarf Kingfisher (Figure 4). 


\section{International Journal of Zoology and Animal Biology}

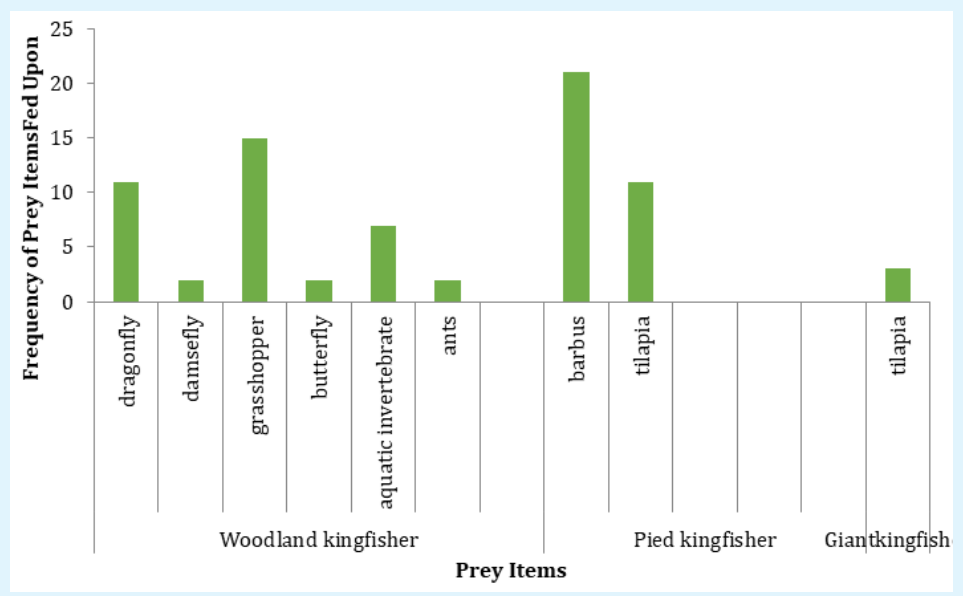

Figure 1: Different prey Items fed upon by Kingfisher (woodland) at Opa Reservoir.

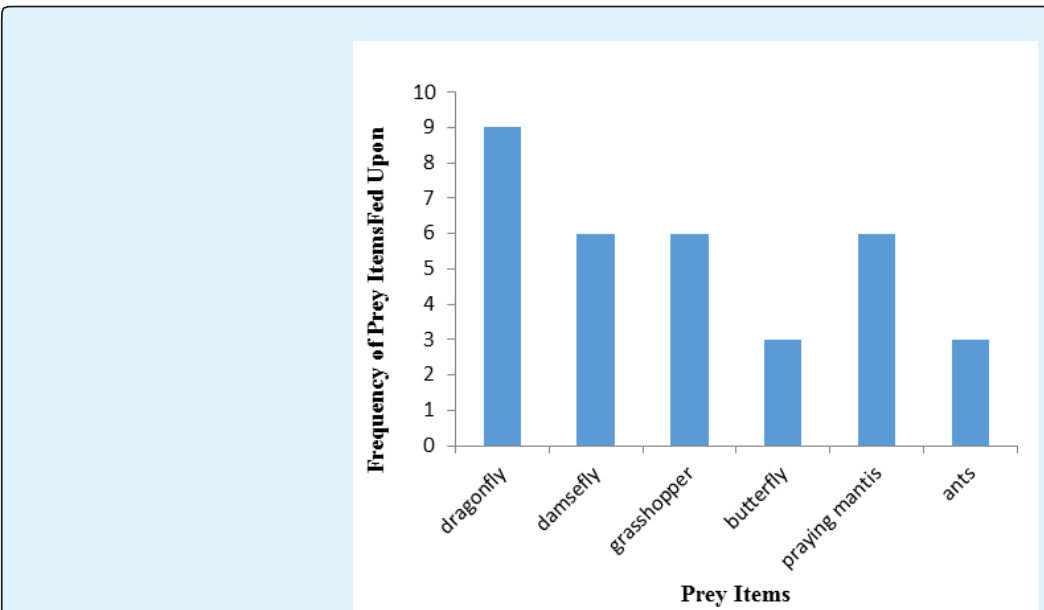

Figure 2: Different prey Items fed upon by Kingfisher (woodland) at Osu Reservoir.

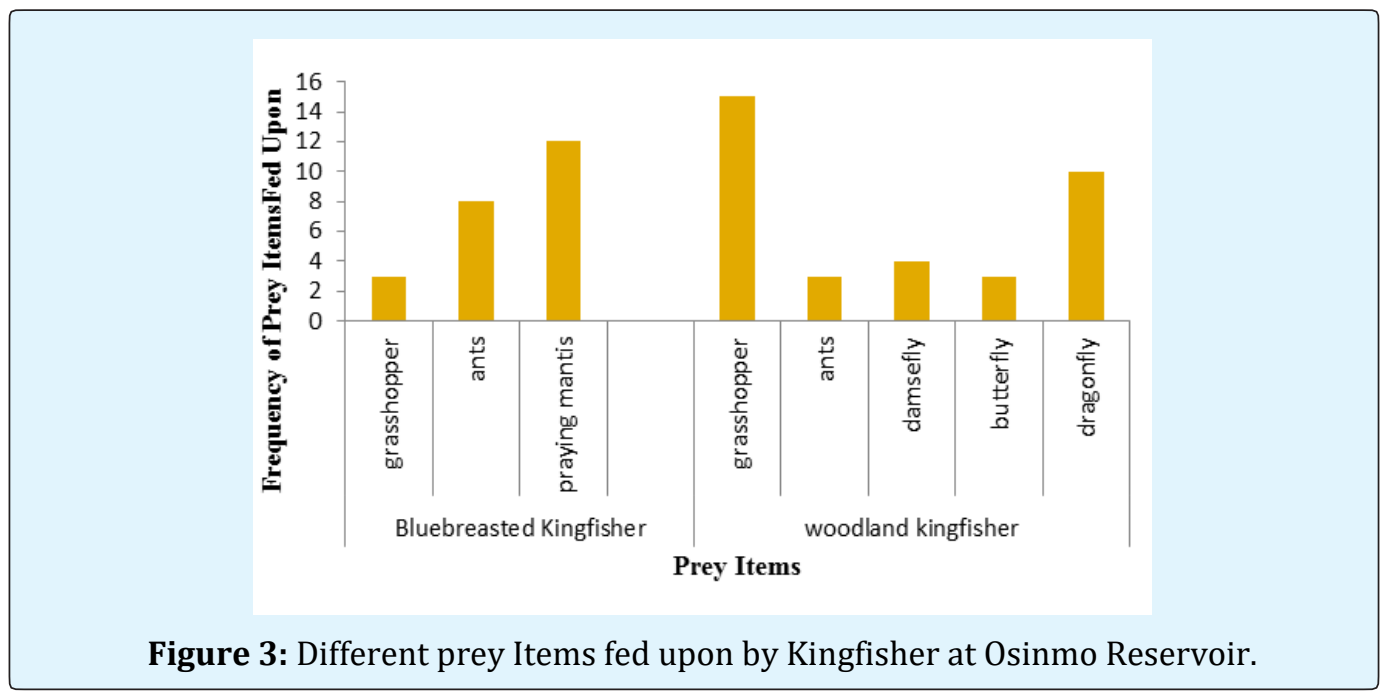




\section{International Journal of Zoology and Animal Biology}

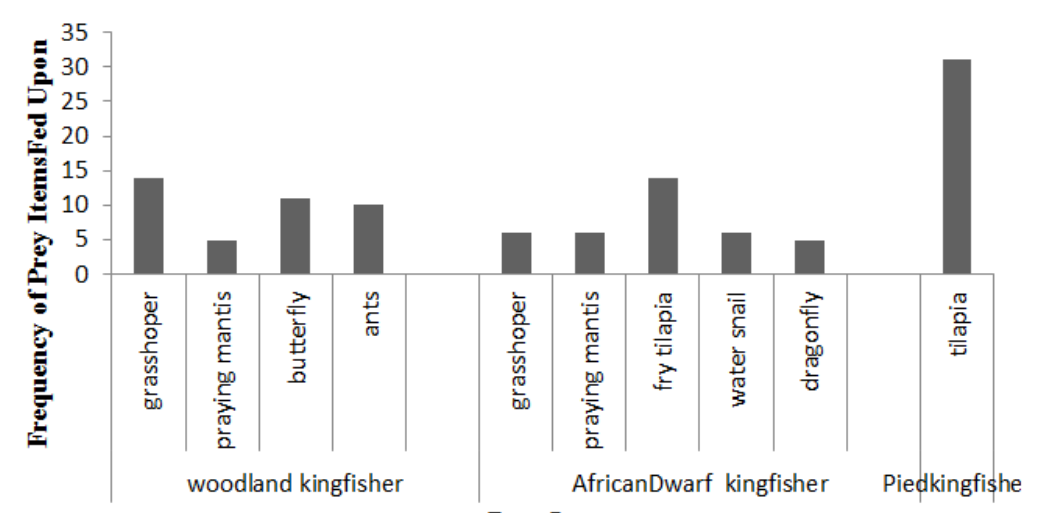

Prey Items

Figure 4: Different prey Items fed upon by Kingfisher at Akinrinade Reservoir.

\section{Preference of Different Food Items Preyed by Kingfisher Across the Sites Using their Faecal Sample}

The faecal analysis revealed different food items preyed upon by kingfisher at all the studied sites identified to their species level though not all the food items were found in their faecal samples. In Opa
Reservoir, the ants had the highest percentage of occurrence followed by grasshopper and seeds of Mimosa pudica for woodland kingfisher species (Table 7), while faecal samples of pied kingfishers and giant kingfisher had tilapia as its highest percentage occurrence. Also in Osu Reservoir, dragonfly had the highest percentage while butterfly had the lowest percentage (Table 8).

\begin{tabular}{|c|c|c|c|c|c|c|c|c|}
\hline \multicolumn{9}{|c|}{ Prey Items } \\
\hline $\begin{array}{c}\text { Common } \\
\text { name of } \\
\text { Kingfisher }\end{array}$ & Common name & Order & Family & Habitat & Species & $\begin{array}{l}\text { Identified } \\
\text { Body Parts }\end{array}$ & $\begin{array}{c}\text { No of } \\
\text { Occurence }\end{array}$ & $\%$ \\
\hline \multirow{8}{*}{ Woodland } & Dragonfly & Odonata & Libellulidae & Terrestrial & $\begin{array}{c}\text { Erythrodiphax } \\
\text { umbrata }\end{array}$ & Wing & 7 & 14.5 \\
\hline & Dragonfly & Odonata & Aeshnidae & Terrestrial & Boyeria vinosa & Wing & 5 & 9 \\
\hline & Ant & Hymenoptera & Formicidae & Terrestrial & Pheidole pallidula & Abdomen & 15 & 27.3 \\
\hline & Grasshopper & Orthoptera & Acrididae & Terrestrial & Oxya hyla & Femur & 8 & 14.5 \\
\hline & Grasshopper & Orthoptera & Acrididae & Terrestrial & $\begin{array}{l}\text { Hetetracris } \\
\text { annulosa }\end{array}$ & Tibia & 2 & 3.6 \\
\hline & Butterfly & Lepidoptera & Nymphalidae & Terrestrial & Danaus plexippus & Wing & 3 & 5.4 \\
\hline & \multicolumn{8}{|c|}{ Unidentified food items } \\
\hline & $\begin{array}{c}\text { Seeds of Mimosa } \\
\text { pudica }\end{array}$ & Fabales & Fabaceae & Terrestrial & Mimosa pudia & Seed & 8 & 14.5 \\
\hline \multirow{5}{*}{ Pied } & Barbus & Cypriniformes & Cyprinidae & Aquatic & $\begin{array}{l}\text { (Enteromirus } \\
\text { callipterus) }\end{array}$ & Scale & 2 & 3.6 \\
\hline & Barbus & Cypriniformes & Cyprinidae & Aquatic & (Enteromirus spp) & Scale & & \\
\hline & Tilapia & Perciformes & Cichlidae & Aquatic & (Coptodon zilli) & Bones & 5 & 9 \\
\hline & Tilapia & Perciformes & Cichlidae & Aquatic & $\begin{array}{l}\text { (Coptodon } \\
\text { guinensis) }\end{array}$ & Bones & 5 & 9 \\
\hline & Tilapia & Perciformes & Cichlidae & Aquatic & $\begin{array}{c}\text { (Sarotherodon } \\
\text { galilaeus) }\end{array}$ & Bones & 5 & 9 \\
\hline
\end{tabular}




\section{International Journal of Zoology and Animal Biology}

\begin{tabular}{|c|c|c|c|c|c|c|c|c|}
\hline & Tilapia & Perciformes & Cichlidae & Aquatic & $\begin{array}{c}\text { (Hemicromis } \\
\text { fasciatus) }\end{array}$ & Bones & 5 & 9 \\
\hline Giant & Tilapia & Perciformes & Cichlidae & Aquatic & $\begin{array}{c}\text { (Hemicromis } \\
\text { fasciatus) }\end{array}$ & Bones & 5 & 9 \\
\hline
\end{tabular}

Table 7: Common Name, Order, Family and Species of Identified Food Items found in the Faecal Samples of Kingfishers in Opa Reservoir. (Total Number $=55)$.

\begin{tabular}{|c|c|c|c|c|c|c|c|c|}
\hline \multicolumn{9}{|c|}{ prey Items } \\
\hline $\begin{array}{l}\text { Common } \\
\text { name of }\end{array}$ & $\begin{array}{l}\text { Common } \\
\text { name }\end{array}$ & Order & Family & Habitat & Species & $\begin{array}{l}\text { Identified } \\
\text { Body Part }\end{array}$ & $\begin{array}{c}\text { No of } \\
\text { Occurence }\end{array}$ & $\%$ \\
\hline \multirow{6}{*}{ Woodland } & Grasshopper & Orthoptera & Acrididae & Terrestrial & Chorthippus brunneus & Hind leg & 4 & 16.7 \\
\hline & Grasshopper & Orthoptera & Acrididae & Terrestrial & Eyprepocenemis plorans & Femur & 5 & 20.8 \\
\hline & Butterfly & Lepidoptera & Nymphalidae & Terrestrial & Dananus plexippus & Wing & 3 & 12.5 \\
\hline & Dragonfly & Odonata & Libellulidae & Terrestrial & Micrathyria aequalis & Wing & 7 & 29.2 \\
\hline & Ant & Hymenoptera & Formicidae & Terrestrial & Dorylus helvolus & Thorax & 5 & 20.8 \\
\hline & $\begin{array}{l}\text { Unidentified } \\
\text { food items }\end{array}$ & & & & & & & \\
\hline
\end{tabular}

Table 8: Common Name, Order, Family and Species of Identified Food Items found in the Faecal Samples of Kingfishers in Osu Reservoir. (Total Number=24).

\begin{tabular}{|c|c|c|c|c|c|c|c|c|}
\hline \multicolumn{9}{|c|}{ Prey items } \\
\hline $\begin{array}{c}\text { Common } \\
\text { name of } \\
\text { Kingfisher }\end{array}$ & $\begin{array}{c}\text { Common } \\
\text { Name }\end{array}$ & Order & Family & Habitat & Species & $\begin{array}{l}\text { Identified } \\
\text { Body Part }\end{array}$ & $\begin{array}{c}\text { No of } \\
\text { Occurrence }\end{array}$ & $\%$ \\
\hline \multirow{6}{*}{ Woodland } & Dragonfly & Odonata & Aeshnidae & Terrestrial & Boyeria vinosa & Wing & 6 & 12.8 \\
\hline & Ant & Hymenoptera & Formicidae & Terrestrial & $\begin{array}{l}\text { Pheidole } \\
\text { pallidula }\end{array}$ & Thorax & 10 & 21.3 \\
\hline & Honey bee & Hymenoptera & Apidae & Terrestrial & Apis mellifera & Wing & 3 & 6.3 \\
\hline & Snail & Achatinoidea & Achatinidae & Aquatic & $\begin{array}{l}\text { Limicolaria } \\
\text { flammea }\end{array}$ & Shell & 10 & 21.3 \\
\hline & Butterfly & Lepidoptera & Nymphalidae & Terrestrial & Cynthia cardui & Wing & 4 & 8.5 \\
\hline & \multicolumn{8}{|c|}{ Unidentified food item } \\
\hline \multirow{4}{*}{ Blue breasted } & Grasshopper & Orthoptera & Acrididae & Terrestrial & $\begin{array}{c}\text { Chorthippus } \\
\text { brunneus }\end{array}$ & Tibia & 3 & 6.3 \\
\hline & Butterfly & Lepidoptera & Nymphalidae & Terrestrial & $\begin{array}{l}\text { Dananus } \\
\text { plexippus }\end{array}$ & Wing & 5 & 10.6 \\
\hline & Ants & Hymenoptera & Formicidae & Terrestrial & Dorylus helvolus & Thorax & 6 & 12.8 \\
\hline & $\begin{array}{l}\text { Unidentified } \\
\text { food item }\end{array}$ & & & & & & & \\
\hline
\end{tabular}

Table 9: Common Name, Order, Family and Species of Identified Food Items found in the Faecal Samples of Kingfishers in Osinmo Reservoir. (Total Number $=47$ ).

At Osinmo Reservoir, snail and ants had the highest percentage of occurrence using their faecal sample while honey bee had the lowest percentage for woodland kingfisher (Table 9); Blue breasted kingfisher had ants as its most consumed prey, followed by butterfly while grasshopper had the least. At Akinrinade Reservoir, butterfly had highest percentage followed by dragonfly and grasshopper for woodland kingfisher while pied kingfisher had tilapia fish as its highest percentage of 
occurrence, African dwarf kingfisher had ant as the highest occurrence and least was grasshopper (Table 10).

\begin{tabular}{|c|c|c|c|c|c|c|c|c|}
\hline \multicolumn{9}{|c|}{ Prey Items } \\
\hline $\begin{array}{l}\text { Common } \\
\text { name of } \\
\text { Kingfisher }\end{array}$ & English Name & Order & Family & Habitat & Species & $\begin{array}{l}\text { Identified } \\
\text { Body Part }\end{array}$ & $\begin{array}{c}\text { No of } \\
\text { Occurrence }\end{array}$ & $\%$ \\
\hline \multirow{8}{*}{ Woodland } & Butterfly & Lepidoptera & Pieridae & Terrestrial & Colias alphera & Wing & 5 & 10.6 \\
\hline & Grasshopper & Orthoptera & Acrididae & Terrestrial & Oxyla chinensis & Tibia & 3 & 6.4 \\
\hline & Grasshopper & Orthoptera & Acrididae & Terrestrial & Oxya hyla & Hind leg & 2 & 4.3 \\
\hline & Dragonfly & Odonata & Libellulidae & Terrestrial & $\begin{array}{c}\text { Erythrodiphax } \\
\text { umbrata }\end{array}$ & Head & 3 & 6.4 \\
\hline & Ant & Hymenoptera & Formicidae & Terrestrial & Dorylus helvolus & Thorax & 2 & 4.3 \\
\hline & Beetle & Coleoptera & Chrysomelidae & Terrestrial & Donacia simplex & Wing & 1 & 2.1 \\
\hline & $\begin{array}{c}\text { Seeds of Mimosa } \\
\text { pudica }\end{array}$ & Fabales & Fabaceae & Terrestrial & Mimosa pudica & Seed & 3 & 6.4 \\
\hline & \multicolumn{8}{|c|}{ Unidentied food items } \\
\hline \multirow{3}{*}{ African dwarf } & Grasshopper & Orthoptera & Acrididae & Terrestrial & Orbillus coeruleus & Hind leg & 4 & 8.5 \\
\hline & Grasshopper & Orthoptera & Acrididae & Terrestrial & Oxya hyla & Hind leg & 3 & 6.4 \\
\hline & Grasshopper & Orthoptera & Acrididae & Terrestrial & $\begin{array}{c}\text { Chorthippus } \\
\text { brunneus }\end{array}$ & Hind leg & 1 & 2.1 \\
\hline \multicolumn{9}{|c|}{ Prey Items } \\
\hline $\begin{array}{c}\text { Common name } \\
\text { of Kingfisher }\end{array}$ & Common Name & Order & Family & Habitat & Species & \begin{tabular}{|l|} 
Identified \\
Body Part \\
\end{tabular} & \begin{tabular}{|c|} 
No of \\
Occurrence \\
\end{tabular} & $\%$ \\
\hline \multirow[t]{3}{*}{ African dwarf } & Dragonfly & Odonata & Libellulidae & Terrestrial & $\begin{array}{c}\text { Erythrodiphax } \\
\text { umbrata }\end{array}$ & Wing & 4 & 8.5 \\
\hline & Butterfly & Lepidoptera & Nymphalidae & Terrestrial & Danaus plexippus & Wing & 3 & 6.4 \\
\hline & Ant & Hymenoptera & Formicidae & Terrestrial & Pheidole pallidula & Thorax & 8 & 17 \\
\hline \multirow[t]{5}{*}{ Pied } & Tilapia & Perciformes & Cichlidae & Aquatic & Tilapia digeti & Bone & 5 & 10.6 \\
\hline & Tilapia & Perciformes & Cichlidae & Aquatic & $\begin{array}{c}\text { Orechromis } \\
\text { niloticus }\end{array}$ & Bone & 5 & 10.6 \\
\hline & Tilapia & Perciformes & Cichlidae & Aquatic & $\begin{array}{l}\text { Hemichromis } \\
\text { fasciatus }\end{array}$ & Bone & 5 & 10.6 \\
\hline & Down feathers & & & & & & & \\
\hline & $\begin{array}{c}\text { Unidentified food } \\
\text { item }\end{array}$ & & & & & & & \\
\hline
\end{tabular}

Table 10: Common Name, Order, Family and Species of Identified Food Items found in the Faecal Samples of Kingfishers in Akinrinade Reservoir. (Total Number $=47$ ).

\section{Discussion}

One of the most important features of waterways is the biodiversity that they support and many are designated as the bird's habitats [17]. A number of bird species of significance in Nigeria occur in the waterways including the Kingfisher Alcedinidae. Protection of waterways was fundamental to the success of this species, and many other flora and fauna that depend on riparian habitats the majority of the birds observed during the study were resident species. The species include the Woodland, Giant, Pied, Blue breasted and the African dwarf kingfishers. Woodland Kingfisher was observed in all the study sites. An important observation was that the bird diversity and abundance (richness) varied across sites. The highest (766) abundance of species were observed in Opa Reservoir. This may be influenced by various factors, such as wetland provision of food for the birds in form of plants, vertebrates and invertebrates. Some also forage for food in wetland soil, some in the water column, and some use the dry landscape, along the streams [18]. Also, Osu Reservoir had lowest (136) abundance of species observed. This low richness of species at the site may be as a result of quality of the 


\section{International Journal of Zoology and Animal Biology}

environment and quantity of food which was in agreement with the findings of Lameed, et al. [19] who observed low abundance of birds (kingfisher) due to quality of the vegetation in the study of species diversity and abundance of wild birds in Dagona-Waterfowl Sanctuary Borno State, Nigeria. In Nigeria, the dry season is categorized by the drying out of small water bodies, which causes a congregation of water-birds at larger stable water bodies. The lower numbers of kingfishers observed in some of the sampling sites during the wet season were due to the dispersal of kingfishers to breed. They move away from large lakes into smaller pans that form seasonally and are likely to have lower risks of predation and disturbance than the larger water [20]. Food habits were observed for all the months throughout the study period. The birds were watched from dawn to dusk as most of the species are diurnal. During preying, the prey items especially fishes were observed and identified immediately by a pair of binoculars. It was observed that kingfishers preyed on several species of insects (dragonfly, grasshopper, damselfly, butterfly, praying mantis and ants), fish (tilapia, fry of tilipia and barbus) and also snail. This result was in line with the findings of Islam and Kamruzzaman, et al. who reported that kingfishers fed largely on insects such as grasshoppers, crickets, mantises, scarabs and other beetles, ants, winged termites, locusts and dragonflies. Wikipedia [11] also confirmed that kingfishers mainly hunt large crustaceans, insects, earthworms, rodents, snakes, fish, and frogs. The diversity of prey item consumed during this study suggested that kingfishers were voracious and take different types of prey that comes their ways particularly invertebrates. Soud, et al. [21] also buttressed the statement that the main cause of diet selection might be due to the opportunistic feeding habit of kingfishers to maintain their daily food needs.

Faecal samples that were used to ascertain the food items picked by various kingfishers only reviewed the hard undigested parts of the prey items according to Pierce, et al. [22] who reported that faecal samples only review the hard parts in the faecal samples. The faecal samples from their roosting and nesting sites were collected. The noninvasive method of faecal samples examined revealed that woodland kingfishers fed on insects and also seeds of Mimosa pudica which also were found in their faecal samples in the reservoirs where Mimosa pudica was present [23]. Conclusively, Blue breasted kingfisher in this study was revealed to be insectivorous, African dwarf kingfisher fed on both insects and water snail while pied kingfishers was found to be piscivorous with what was reviewed in their faecal sample. It was however noted that soft bodied preys were never observed in the faecal samples due to their lack of hard parts. Kingfishers observed occupied a wide range of areas around the water bodies and its surrounding and also pick diversity of food materials including seed of Mimosa pudica plant thereby limiting interrelationship among the species of kingfishers observed within the reservoirs. Perch height and foraging areas differed among the species of kingfishers observed which revealed that they occupied different foraging niche within the reservoirs.

\section{Conclusion}

Food and feeding behaviour of kingfishers were greatly influenced by the quality of their environment. Woodland kingfishers appear to be the most abundant across the entire reservoir studied because of their ability to adapt to all kind of environment around the reservoir. They are also voracious in their feeding habit. Pied and Giant kingfishers are piscivorous, they also devoid fingerlings in the fish pond among the species of kingfishers studied while Blue breasted kingfisher was Insectivorous, African dwarf kingfishers fed on both insects and water snail. Different species of kingfishers fed on varieties of prey items which did not give room for competitions and niche overlap between different species of kingfishers.

\section{References}

1. Sibley CG, Ahlquist JE (1990) Phylogeny and classification of birds. A study in molecular evolution, New Haven and London: Yale University Press pp: 1967.

2. Moyle RG (2006) A Molecular Phylogeny of Kingfishers (Alcedinidae) with insights into early biogeographic history. The Auk 123(2): 487.

3. Sibley CG, Monroe BL (1988) A classification of the living birds of the worlds based on DNA-DNA hybridization studies. The Auk 105(3): 409-423.

4. Fry C (2003) Kingfishers. In: Perrins C, et al. (Eds.), The New Encyclopedia of birds. Oxford University Press pp: 366-371.

5. Fry C, Fry K, Harris A (1992) Kingfishers, Bee-eaters and Rollers. Prineton University Press 10: 95-213. 


\section{International Journal of Zoology and Animal Biology}

6. Krueper D (2001) Kingfishers. In: Elphick C, Dunning J, Dsibley, et al. (Eds.), The Sibley Guide to Bird life and Behaviour. New York: Alfred A Knopf pp: 370372.

7. Remsen JV (1991) Community ecology of Neotropical kingfishers. University of California Publications in Zoology 124: 0068-6506.

8. Woodall P (2001) Family Alcedinidae (Kingfishers). In: delHoyo J, Elliott A, Sargatal J, et al. The handbook of the birds of the world. Barcelona: Lynx Edicions 6: 130-187.

9. Campos F, Fernandez A, Gutierrez Corchero F, Martin Santos F, Santos P (2000) Diet of the Eurasian kingfisher (Alcedo atthis) in Northern Spain. Folia zoological 49: 115-121.

10. IUCN (2003) IUCN Red List of Threatened Species: Journal Noami 6(1\&2): 17-29.

11. Wikipedia (2018) Common Kingfisher.

12. Omolafe 00 (2008) Some Aspects of the Biology of Tilipia zilli (Gervais) (Pisces: Cichlidae) in Opa Reservoir, Ile-Ife, Nigeria. Journal of Science and Technology 28(1): 49-56.

13. Oguntoyinbo JS (1982) Climate II and III Precipitation I and II. In: Barbour KM, Oguntoyinbo JS, Onyemelukwe JO, Nwafor JC, et al. (Eds.), Hodder and Stoughton, London pp: 16-18.

14. Ndifon GT, Ukoli FMA (1989) Ecology of freshwater snails in South-Western Nigeria. I: Distribution and habitat preferences. Hydrobiologia 171: 231-253.

15. Komolafe 00, Arawomo GAO (2008) Preliminary observations on fish species in a newly impounded Osinmo Reservoir. Turkish Journal of Fisheries and Aquatic Sciences 8: 289-292.
16. Borrow Nik, Ron Demey (2004) Field Guide; Birds of Western Africa. Christopher Helm. London 2: 76-179

17. Keeffe OC, Dromey M (2004) Designation of sites for fish under the EU habitats directive. Biology and Environment 104B(3): 103-105.

18. Hansen AJ, Knight RL, Marzluff JM (2005) Effects of exurban development on biodiversity: Patterns, mechanism and research needs. Ecological Application 15(6): 1893-1905.

19. Lameed GA (2011) Species diversity and abundance of wild birds in Dagona-Waterfowl Sanctuary Borno State, Nigeria. African Journal of Environmental Science and Technology 5(10): 855-866.

20. Hockey PA, Dean WJ, Ryan PG (2005) Roberts birds of southern Africa. $7^{\text {th }}$ (Edn.), Cape Town: Trustees of the John Voelcker Bird Book Fund 4: 325-4113.

21. Soud R., Mazumdar K, Gupta A (2010) Predation by White-throated Kingfisher Halcyon smyrnensis on Common wolf Snake Lycodonaulicus (Linnaeus). International Journal of environment and Biodiversity 1(1): 53-54.

22. Pierce GJ, Diack JSW, Boyle PR (1991) Identification of fish Otoliths and bones in faeces and digestive tracts of seals. London. Journal of Zoology 224: 320328.

23. Islam M, Kamruzzaman M (2008) Halcyon smyrnensis. In: Siddiqui KU, Islam MA, Kabir SMH, Ahmad M, Ahmed ATA, Rahman AKM, Haque EU, Ahmed ZU, Begum ZNT, Hassan MA, Khondker M, Rahman MM, et al. (Eds.), Encyclopedia of Flora and Fauna of Bangladesh. Birds Asiatic Society of Bangladesh, Dhaka 26: 75-76. 